\title{
KORUMA AMAÇLI TOPRAK EDINIMLERİ TOPRAK GASPININ BİR PARÇASI VE TAMAMLAYICISI OLARAK DEĞERLENDİRILEBİLIR Mİ?
}

Araştırma Makalesi / Research Article

\author{
AK KURAN, S. (2020). Koruma Amaçlı Toprak \\ Edinimleri Toprak Gaspının Bir Parçası ve Tamamlayıcısı \\ Olarak Değerlendirilebilir Mi?. Nevşehir Hacı Bektaş Veli \\ Üniversitesi SBE Dergisi, 10(2), 532-548. \\ DOI: $10.30783 /$ nevsosbilen. 748167
}

Gelis Tarihi: 04.06.2020

Kabul Tarihi: 19.12 .2020

E-ISSN: 2149-3871

Dr. Sabriye AK KURAN

Nevşehir Hacı Bektaş Veli Üniversitesi, İktisadi ve İdari Bilimler Fakültesi, Kamu Yönetimi Bölümü akkuran@nevsehir.edu.tr

ORCID No: 0000-0001-6625-1521

\begin{abstract}
ÖZ
İnsanlık tarihi boyunca gıda insanların temel ihtiyaçlarından birisi olmuş ve küresel nüfustaki artışa bağlı olarak gıda ürünlerine olan talep de sürekli artmıştır. Sınırlı bir kaynağa sahip olan gezegenimizde bu talebin karşılanabilmesi, toprağın metalaştırılması yoluyla gerçekleştirilmiştir. Literatürde bu olguya toprak gasp1 denilmektedir.

Buradan hareketle çalışmada, ilk olarak toprak gaspı tartışmalarına ilişkin teorik bir çerçeve çizilmektedir. Bu kapsamda toprak gaspı kavramı, toprak gaspında arazi kullanım amaçları ve gaspın etkileri analiz edilmektedir. İkinci olarak, teorik düzeydeki tartışmaların uygulamaya nasıl yansıdığı incelenmekte ve koruma amaçlı toprak ediniminin (yeşil gasp) toprak gaspı kapsamında değerlendirilip değerlendirilemeyeceği tartışılmaktadır. Bunun için dünyanın çeşitli ülkelerinde gerçekleştirilen toprak gaspı girişimleri ve sonuçları çözümlenmektedir. Arjantin, Meksika, Kolombiya, Mozambik ve Uganda'daki yeşil gasp örnekleri koruma amaçlı toprak ediniminin toprak gaspının tamamlayıcısı ve destekleyicisi olduğunu göstermektedir. Yeşil gasp girişimlerinde temel amacın çevresel değerleri korumak olduğu iddia edilmekle birlikte, bu girişimlerin sonucunda ortaya çıkan tablo toprak gaspı ile hemen hemen aynıdır. Ayrıca söz konusu saha araştırmaları toprağı metalaştırma yoluyla korumanın mümkün olamayacağına ilişkin işaretlerle doludur.
\end{abstract}

Anahtar Kelimeler: Toprak Gaspı, Yeşil Gasp, Metalaştırma, Koruma, Gıda Egemenliği.

\section{CAN LAND ACQUISITIONS FOR PROTECTION PURPOSES BE EVALUATED AS A PART AND COMPLEMENT OF LAND GRABBING?}

\section{ABSTRACT}

Food has been one of the basic needs of people throughout the history of mankind and the demand for food products has increased continuously along with the rise of the global population. In our planet, strictly limited in terms of resources, the food demand was met by commodification of the land which is called the land grabbing in literature.

From this point of view, firstly, a theoretical framework regarding the land grabbing discussions is drawn. In this context, the concept of land grabbing, land use purposes and the effects appropriation are analyzed. Secondly, it is examined how the theoretical discussions are reflected in the practice and it is discussed whether the land acquisition for conservation (green grabbing) can be evaluated within the scope of land grabbing. For this, land grabbing attempts and their results in various countries of the world are analyzed. Examples of green grabbing in Argentina, Mexico, Colombia, Mozambique and Uganda show that land acquisition for protection purposes is a supplement and supporter of land grabbing. Although it is claimed that the main purpose of green grabbing initiatives is to protect environmental values, the picture emerging as a result of those attempts is almost the same as land grabbing. In addition, the field surveys done in this paper are full of signs that it is not possible to protect the land through commodification.

Keywords: Land Grabbing, Green Grabbing, Commodification, Protection, Food Sovereignity. 


\section{GIRISS}

Toprak hem insanların hem de insan dışındaki varlıkların yaşamlarını devam ettirebilmeleri için gerekli ve önemli bir doğal kaynaktır. Yaşamın devamlılığı bakımından bu denli anlamlı bir kaynak olan toprağın korunması ve sürdürülebilir bir şekilde kullanılması gerekirken bunun aksine korunmadığı ve zaman geçtikçe daha da yok edildiği görülmektedir. Toprak üzerinde yaratılan baskının sebepleri farklılık göstermekle birlikte genel olarak tarım, sanayi, inşaat, madencilik ve turizm gibi sektörler ve bu sektörlerde gerçekleștirilen çeșitli faaliyetlerdir. Son dönemlerde hem dünya hem de Türkiye gündeminde sıkça yer bulan ve farklı boyutlarıyla ele alınan toprak gaspı (toprak satın alma/kiralama) girişimleri de söz konusu baskıyı arttıran faktörlerden birisidir.

Akademik literatürde toprak satın alma, kiralama ve gasp kavramları birbirlerinin yerine kullanılmakla birlikte detaylı bakıldığında bu kavramlar iki farklı bakış açısını yansıtmaktadır. Bunlardan birincisinde, bir ülkenin başka bir ülkenin topraklarını satın alma/kiralama girişimine olumlu açıdan yaklaşılmaktadır. Bu tarafı savunanlara göre, toprak satın alma veya kiralama yeni iş imkânları yaratma, kırsal altyapıyı geliştirme ve kırsal yoksulluğu azaltma gibi konularda birtakım olanaklar sağladığı gerekçesiyle desteklenmekte ve toprak edinimi gasp olarak değerlendirilmemektedir (Von Braun ve Meinzen-Dick, 2009: 2). İkinci taraf ise, toprak satın alma veya kiralama eylemlerini gasp olarak nitelendirmekte ve bu eylemlere karşı mücadeleyi teşvik etmektedir. Bu grupta yer alanların argümanlarına göre, toprak edinimleri yoksul insanların topraklarından çıkarılmalarına, geçim kaynaklarını kaybetmelerine, küçük üreticilerin zarar görmesine, yoğun tarım yapılmasından kaynaklı olarak toprak yapısının tahrip olmasına ve ekolojik sürdürülebilirliğin bozulmasına yol açmaktadır (Von Braun ve Meinzen-Dick, 2009: 2). Dolayısıyla ülkeler arasında veya ülkelerin kendi içlerinde gerçekleşen toprak edinimlerini tek bir kavram altında toplamak hatalı olacaktır. Çünkü toprak satın alma/kiralama ile toprak gaspı kavramının içeriği işaret ettiği etkiler bakımından farklılaşmaktadır. Bu çalışmada da toprak gaspı kavramı tercih edilmekte ve çözümlemeler bu kavrama referansla yapılmaktadır.

Dünya üzerinde ne kadarlık bir alanın gasp edildiğine ilişkin kesin bir tahminde bulunmak kolay değildir. Bunun sebebi ise, sürecin kayıt altına alınmasının zor olması, bazı anlaşmaların gizli yapılması ve işlemlerin şeffaf bir şekilde yürütülmemesidir. Bununla birlikte, söz konusu toprak anlaşmaları ile ilgili verilere ulaşmaya ve bu alandaki belirsizlikleri gidermeye çalışan birtakım kurumlar da yok değildir (Broughton, 2013: 25). Bağımsız bir küresel arazi izleme girişimi olan Arazi Matrisi'nden bu kapsamda bahsedilebilir. Arazi Matrisi tarafindan sunulan rakamlar hükümet programları, akademik araştırmalar, şirket web siteleri, medya haberleri ve ulaşılabilir birkaç anlaşma gibi çeşitli kaynaklara dayandırılmaktadır (Oxfam, 2011: 5). Arazi Matrisi 2000 ve 2011 yılları arasında yabancı yatırımcılara satılan, kiralanan, ruhsat verilen veya müzakere edilen alan miktarının 227 milyon hektar olduğunu tahmin etmektedir (Oxfam, 2011: 5).

Dünya Bankası (DB) öncülügünde hazırlanan araştırmalarda da bu tahmini haklı çıkarır nitelikte verilere ulaşılmaktadır. Kurumun yayınladığ fiyatlarında yüksek artışın yaşandığı 2007-2008 kriz döneminden sonraki ilk yılda (2009) bile yaklaşık 56 milyon hektar alanı kapsayan büyük ölçekli tarım arazisi anlaşması yapıldığı iddiası bu anlamda dikkat çekicidir. Üstelik bu talebin \%70'inden daha büyük bir kısmının Afrika'daki Etiyopya, Kenya, Mozambik ve Sudan ${ }^{1}$ gibi ülkelere yönelik olduğu belirtilmektedir (Deininger vd., 2011: 14). Büyük ölçekli tarımsal arazi edinimi ve yatırımlarının hedefinde yalnızca Afrika ülkeleri yer almamaktadır. Bunların arasında Arjantin, Brezilya, Şili, Kolombiya ve Peru gibi Latin Amerika ülkeleri; Kamboçya, Çin, Gürcistan, Hindistan, Endonezya ve Malezya gibi Asya ülkeleri de bulunmaktadır. Aşağıdaki tablo toprak gaspı açısından öne çıkan yatırımcı ve hedef ülkelerin kapsamının genişliğini gözler önüne sermektedir.

Tablo 1: En Fazla Yatırım Yapan ve Yapılan Ülkeler, 2019

\footnotetext{
${ }^{1}$ Burada özellikle belirtmek gerekir ki, Türkiye de Sudan'dan toprak kiralayan ülkelerden birisidir. Gıda Tarım ve Hayvancılık Bakanlığı, Sudan Tarım ve Sulama Bakanlığ ile yaptığı görüşmeler neticesinde anlaşmaya varmış ve 5 milyon dönüm (5 bin kilometrekare büyüklüğünde) büyüklüğünde bir araziyi tarımsal üretim yapmak amacıyla 99 yıllığına kiralamıştır. Konuyla ilgili daha fazla bilgi için bkz: (Özkaya, 2018).
} 


\begin{tabular}{|l|c|l|c|}
\hline \multicolumn{4}{|c|}{ Illk 10 Yatırımcı ve Hedef Ülke } \\
\hline \multicolumn{2}{|c|}{ Yatırımcı Ülkeler } & \multicolumn{2}{c|}{ Hedef Ülkeler } \\
\hline Çin & $7,719,518$ ha & Rusya Federasyonu & $10,244,037$ ha \\
\hline Rusya Federasyonu & $6,282,876$ ha & Papua Yeni Gine & $3,767,303$ ha \\
\hline ABD & $6,008,576$ ha & Ukrayna & $3,448,824$ ha \\
\hline Malezya & $4,448,425$ ha & Brezilya & $3,400,838$ ha \\
\hline Japonya & $3,352,720$ ha & Endonezya & $3,265,347$ ha \\
\hline İsviçre & $3,208,318$ ha & Güney Sudan & $2,071,892$ ha \\
\hline Brezilya & $2,406,329$ ha & Mozambik & $1,965,403$ ha \\
\hline Arap Emirlikleri & $2,343,147$ ha & Arjantin & $1,760,075$ ha \\
\hline Birleşik Krallık & $2,180,273$ ha & Liberya & $1,441,389$ ha \\
\hline Hollanda & $2,124,133$ ha & Guyana & $1,375,001$ ha \\
\hline \multicolumn{2}{|c|}{ (Land Matrix, 2019b) } &
\end{tabular}

Yukarıdaki tablodan da anlaşılacağı üzere, ilk 10'a giren yatırımcı ülkeler sırasıyla Çin, Rusya Federasyonu, ABD, Malezya, Japonya, İsviçre, Brezilya, Arap Emirlikleri, Birleşik Krallık ve Hollanda'dır. Yatırımcıların hedefindeki ülkeler ise, Rusya Federasyonu, Papua Yeni Gine, Ukrayna, Brezilya, Endonezya, Güney Sudan, Mozambik, Arjantin, Liberya ve Guyana'dır. Dikkat edilecek olursa, yatırımcı ülkelerin çoğunun finansal açıdan görece varlıklı ancak doğal kaynaklar bakımından nispeten fakir ülkeler olduğu anlaşllacaktır. Hedeflenen ülkeler için ise, tam tersi bir durumdan söz edilebilir. Üstelik bazı ülkeler (Rusya Federasyonu ve Brezilya gibi) hem yatırımcı hem de hedef ülke kategorisine girebilmektedir.

Az gelişmiş ülkelerdeki verimli tarım topraklarının gelişmiş ülkelerdeki yabancı yatırımcı ve şirketlerin odağına oturması ve toprağın cazip bir mal haline gelmesinin ardında yatan sebepler ise çok çeşitlidir. İklim değişikliği, nüfus artışı, kontrolsüz olarak büyüyen ve yayılan kentler, altyapı projeleri ve uygulamaları, enerji ve ham madde ihtiyacını karşılamak için yapılan madencilik faaliyetleri, artan tarımsal ürün ve arazi fiyatları gibi faktörlerin her biri tarım arazilerini kârlı bir yatırım aracı haline getirmektedir (Heinrich Böll Stiftung, 2015: 38, 42; Su Hakk1 Kampanyas1, 2016). Bir de buna her iki ülke grubundaki gelişmeler eklenince mevcut eğilim katlanarak artmaktadır. Suudi Arabistan'da yaşanan su kıtlığı sorunu, Etiyopya'daki tarım arazisi sıkıntısı, Çin'de değişen tüketim kalıpları, Fransa, Almanya ve ABD gibi ülkelerdeki yükselen arazi fiyatları ve Avrupa Birliği'ndeki $(\mathrm{AB})$ yenilenebilir enerji kaynağı (biyoyakıt vb.) politikaları bu gelişmelere dâhil edilebilir (Heinrich Böll Stiftung, 2015: 38).

Yabancı sermaye tarafindan satın alınan veya kiralanan topraklar kadar bu toprakların hangi amaçlarla kullanıldığı/kullanılacağı da çok önemlidir. Toprak gaspı işlemleri yalnızca tarımsal ürünlere olan talebi karşılamak amacıyla yapılmamaktadır. Bunun yanında toprak gaspı ile ilişkilendirilebilecek yatıım alanlarından bazıları şunlardır: Biyoyakıtlar, besin bitkileri, hayvancılık, gıda dışı tarım ürünleri, kereste ekimi, ormancılık ve tomrukçuluk, karbon yutakları, turizm, sanayi, koruma ve yenilenebilir enerjidir (güneş, rüzgâr, jeotermal, hidrojen ve dalga) (Land Matrix, 2019a). Yani, toprak gaspı gıda ve yakıt üretimi için toprak satın almanın çok daha ötesinde bir işlemdir ve topraklar çok çeşitli amaçları (turizm, doğa koruma ve kentsel büyüme gibi) gerçekleştirmek için satın alınmaktadır (Zoomers, 2010: 442).

Toprak satışlarına ilişkin yapılan anlaşmalar arasında koruma amaçlı olanlar diğerlerine kıyasla üzerinde en az tartışma yürütülen ve çoğu zaman göz ardı edilenlerdir. Hâlbuki toprak gasp1 ve koruma arasındaki ilişki daha fazla araştırılmayı hak eden çok yönlü bir alandır (Blomley vd., 2013: 4). Çünkü ilk bakışta toprağın ve kaynakların çevresel amaçlar için tahsis edilmesi onaylanabilecek ve hatta desteklenebilecek bir girişim olarak düşünülebilir. Ancak uygulamada sürecin böyle işlemediği ve doğanın korunmadığı ortaya çıkmaktadır. Buradan hareketle çalışmada; satın alınan topraklar korumaya tahsis ediliyorsa buna toprak gaspı denilebilir mi, çevresel amaçlar 
için toprağa ve kaynaklara el koyma mümkün olabilir mi, koruma amaçlı toprak edinimi doğaya yönelik tahakkümün yeni şekli midir (Fairhead vd., 2012: 237) ve koruma amaçlı toprak satın alma toprak gaspının bir parçası ve tamamlayıcısı olarak değerlendirilebilir mi? gibi soruların yanıtlarına ulaşılmaya çalışılmaktadır.

\section{TOPRAK GASPI KAVRAMI NE ANLAMA GELMEKTEDİR?}

Koruma amaçlı toprak edinimi (yeşil gasp) ve bu girişimin etkileri konusuna geçmeden önce, toprak gaspı kavramının tanımlanması ve içeriğinin doldurulmasında fayda vardır. Toprak gaspı kavramının üzerinde uzlaşılmış bir tanımı yoktur ve kavramın temel bileşenlerine ilişkin tartışmalar da devam etmektedir. Kavramın anlamına yönelik farklı bakış açıları ve tartışmalı konular olmakla birlikte çeșitli düzeylerde de olsa bu kavramı tanımlama çabaları mevcuttur. Ecoruralis Derneği toprak gaspı kavramının 5 kriter üzerinden tanımlanabileceğini ifade etmektedir. Bu kriterler; boyut, özne, kontrol, yasaya uygunluk ve kullanım şeklidir (Baker-Smith ve Miklos Attila, 2016: 2). Boyut kriteri ile satın alınan toprağın büyüklüğüne işaret edilmektedir. Dernek toprak gaspı kavramı içerisine dâhil edilebilecek arazi miktarının yerel arsa boyutlarına bağlı olarak değişebileceğini vurgulayarak, gaspın boyutunu belirleme noktasında herkesin kendi ülkesindeki arazilere bakmasını ve ortalama büyüklüğü belirleyerek bunun üzerinde kalan alanları gasp olarak nitelendirmesini önermektedir. Özne kriterinde, toprağı gasp edenlerin kimler olduğu sorusu üzerinde durulmaktadır. Derneğe göre, bireyler, gruplar, şirketler, kamu veya özel sektör, hükümet veya hükümet dış1 aktörler, yerli veya yabancı yatırımcılar gibi öznelerin her biri toprak gaspçısı olabilir. Bu nedenle toprak gaspı kavramının belirli gruplar veya kişilerle sınırlandırılması mümkün değildir.

Kontrol kriterinde toprak üzerinde hâkimiyetin nasıl kurulduğu ve bunun hangi yollarla yapıldığı sorusu açıklanmaktadır. Başka bir ifadeyle, bahse konu olan alana nasıl hâkim olunduğu toprak gaspının çerçevelenmesi bağlamında önemli bir unsur olarak kabul edilmektedir. Toprakların kiralanarak, satın alınarak ve toprağı belirli bir şekilde kullanmaya zorlayan sözleşmeler yapılarak kontrol edilebileceği iddia edilmektedir. Dördüncü kriter toprak gaspının yasal ya da yasadışı olması ile ilgilidir. Ecoruralis'e göre, toprak gaspı yasalara uygun olarak yapılabileceği gibi yasa dışı da olabilir. Üstelik toprak gaspı anlaşmalarının çoğunun ulusal ve yerel yasalara bağlı kalınarak gerçekleştirildiğinin altı çizilmektedir. Bununla birlikte, bu yasaların toprak gaspı işlemlerine karşı herhangi bir koruma sağlamadıkları da belirtilmektedir. Kullanım șekli kriterinde ise, toprağın nasıl ve hangi amaçlarla kullanıldığına dikkat çekilmektedir. Toprak gaspçılarının araziyi genellikle özel amaçları için ve araziye zarar verecek şekilde kullandıkları vurgulanmaktadır. Amaç dışı kullanım, arazi spekülasyonu, metalaştırma, kaynak kontrolü ve çıkarımı gibi yöntemlerin tamamının gıda güvenliğini, toprak mülkiyeti ve egemenliğini ve insan haklarını tehdit ettiği ileri sürülmektedir.

Ecoruralis tüm bu kriterlerden yola çıkarak toprak gaspını; herhangi bir kişi ya da kurum tarafindan (kamu veya özel, yerli veya yabancı) herhangi bir yolla (yasal ya da yasadışı) yapılan, köylü çiftçiler, agroekoloji, gıda güvenliği ve insan hakları pahasına spekülasyon, kaynak kontrolü veya metalaştırma gibi amaçlar lehine yerel olarak tipik arazi miktarından daha büyük alanların kontrolü şeklinde tanımlamaktadır (Baker-Smith ve Miklos Attila, 2016: 2). Birleşmiş Milletler Gıda ve Tarım Örgütü (FAO) de yayınlarında toprak gaspı ile ilgili tartışmalara yer vermekte ve bu kavramın temel özelliklerini ortaya çıkarmaya çalışmaktadır. FAO tarafından talep edilen ve Latin Amerika ve Karayip ülkelerindeki (17 ülke) toprak gaspı dinamikleri ve eğilimlerini göstermek amacıyla yapılan ampirik bir çalışmada, toprak gaspı ile ne kast edildiği bilgisine de değinilmektedir. Çalışmada toprak gaspının üç spesifik özelliğinden bahsedilmektedir. Bunlar (Gómez, 2014: 21): Büyük ölçekli arazi edinimlerinin kapsamı, toprak anlaşmalarına yabancı devletlerin ilgisi ve katılımı ve toprak anlaşmalarına dayalı yatırımların bu yatırımları kabul eden ülkelerin gıda güvenliği üzerindeki olumsuz etkileridir.

Toprak gaspı kavramının kapsamını aydınlatmaya çalışanlardan bir diğeri, Uluslararası Arazi Koalisyonu'dur. Söz konusu koalisyonun 2011 yılında yayınladığı Tiran Deklarasyonu'nda aşağıdaki maddelerden bir veya daha fazlasını kapsayan toprak anlaşmalarının gasp olarak değerlendirilebileceği söylenmektedir (International Land Coalition, 2011): 
“- İnsan haklarını özellikle de kadınların eşitlik haklarını ihlâl eden,

- Etkilenen arazi kullanıcılarının özgür bir şekilde ve yeterince bilgilendirilerek alınmış rizalarına dayanmayan,

- Ayrıntılı bir değerlendirmeye dayanmayan veya toplumsal cinsiyet faktörü de dâhil olmak üzere sosyal, ekonomik ve çevresel etkileri yok sayan,

- Faaliyetler, istihdam ve fayda paylaşımı ile ilgili konularda açık ve bağlayıcı taahhütler içeren şeffaf sözleşmelere dayanmayan,

- Etkili bir planlama ve anlamlı bir katılım düzeyine sahip olmayan" anlaşmalar ve bunlara bağlı olarak elde edilen kazanım ve ayrıcalıklar toprak gaspı içerisinde sayılmaktadır.

Dikkat edilecek olursa, Ecoruralis Derneği, Uluslararası Arazi Koalisyonu ve Birleşmiş Milletler Gıda ve Tarım Örgütü'nün bir toprak anlaşmasının gasp kapsamında değerlendirilebilmesi için ortaya attığı koşullar birbirinden oldukça farklıdır. Ancak her üçü için de ortak denilebilecek bir nokta vardır o da etki boyutudur. Biraz daha detaylandıracak olursak, söz konusu tanımlama girişimlerinin hepsinde topraklarını satan tarafların az ya da çok zarar görme durumu ya da olasılığından söz edilmekte ve bu kriter toprak gaspı işlemlerinde gerekli bir bileşen olarak görülmektedir. Elbette ki bu tanımlamaları sorunlu bulanlar ve toprak gaspını farklı şekillerde yorumlayanlar da vardır. ${ }^{2} \mathrm{Bu}$ çalışma kapsamında toprak gaspı ile ilgili bütün tanımlamalara yer vermek mümkün olmayacağı için daha çok ortak bir kriter olan etki boyutuna odaklanılmaktadır.

Ancak burada birkaç hususun belirtilmesinde de fayda vardır. İlk olarak, toprak satın alma/kiralama girişimlerinin gasp olarak değerlendirilmesi durumunda anlaşmalara konu olan farklı boyutlardaki toprakların, onların üzerinde yaşayan ve/veya onu işleyen insanlara sorulmaksızın el değiştirmesinden söz etmek gerekliliğidir. Yani toprak gaspıyla kast edilen istenmeyen ve çoğu zaman zorla gerçekleştirilen mülkiyet değişikliğidir. Bahsi geçen mülkiyet değişikliğinin gerçekleştirilmesi ise, uygulamada çeşitli şekillerde olabilmekte ve hem özel hem de kamusal olarak önemli bir gücün kullanılmasını gerektirmektedir (Feldman, 2012: 975). Bireyleri ve yerli toplulukları topraklarını bırakmaya zorlamak için güç uygulayan toprak gaspçıları, süreci kolaylaştırmak amacıyla devletlerle işbirliği yapmakta ve onların yardımını almaktadır. Devletlerin gönüllü bir alıcının yer aldığı ama istekli bir satıcının yer almadığ toprak gaspı sürecinde tarafsız olması beklenirken adil davranmayıp yoksul kesimlerin aleyhine olacak şekilde güçlü sermayedarların yanında saf tuttuğu görülmektedir (Cochrane, 2016: 2-3). Üstelik pek çok ülkede kırsal topluluklar yabancı yatırımcılar topraklarına göz koyduklarında uygun tazminat olmaksızın kamulaştırma ve zorla tahliyelerle de karşı karşıya kalmaktadır (Graham vd., 2010: 24).

Altı çizilmesi gereken ikinci husus ise, toprak gaspındaki temel amacın toprakların daha kârlı işlemler için kullanılmak isteniyor olmasıdır. Yani toprak satışlarını destekleyenlerin iddia ettiklerinin (yeni iş imkânları sağlama, kırsal altyapıyı geliştirme ve kırsal yoksulluğu azaltma vb) aksine toprak gaspı yerli toplulukların geçim kaynaklarını kaybetmelerinin, yerinden edilmelerinin ve kırsal yoksulluğun devam etmesinin temel sebeplerinden birisidir. Çünkü çok sayıdaki küçük köylü üreticinin elindeki toprağın güçlü gruplar tarafından alınması ve/veya bu topraklara el konulmasının ardındaki temel faktör, yeni bir birikim ve rant arayışıdır. Başka bir ifadeyle, sermayenin arazi kaynaklarını ele geçirmekle ilgilenmesi tamamen kendi menfaatlerini karşılama ihtiyacından kaynaklanmaktadır. Bu ise, sermaye birikiminin devamlılı̆ı̆ı sağlamak için arazilerin yoksulların elinden alındığı ve onların üzerinde baskı kurulduğu anlamına gelmektedir. Bir bakıma toprak gaspı süreci sermayenin mülksüzleştirme yoluyla birikimini arttırmasının bir yolu haline gelmektedir (Kelly, 2011: 683, 685).

\section{TOPRAK GASPINDA ARAZI KULLANIM AMAÇLARI VE GASPIN ETKIILERİ}

Ülkelerin ya da şirketlerin toprak gaspına başvurmalarına sebep olan faktörler çeşitlilik göstermektedir. Toprak satışlarına ilişkin anlaşmalar bazen üretim yapmak amacıyla yapılırken

\footnotetext{
${ }^{2}$ Toprak gaspı tanımlamalarının sorunlu tarafları ve toprak gaspı ile ilgili farklı tanımlar için bkz: (Murmis ve Murmis, 2012: 493, 497); (Borras Jr vd., 2012: 404-405); (Hall vd., 2015: 473-474); (Franco vd., 2013: s. 3-4).
} 
bazen üretim dışı alanları da kapsamaktadır. Bazen de çevresel değerlerin korunmasını sağlamak amacıyla bu yönteme başvurulduğu iddia edilmektedir. Bunların yanında biyoyakıt üretimini sağlamak, gida güvenliğini temin etmek ve spekülasyon gibi etkenler de belirleyici olabilmektedir (Broughton, 2013: 25). Tablo 2, Arazi Matrisi veri tabanındaki tüm anlaşmalarda yer alan yatırım amaçları, amaçtan bahsedilme sayıları ve anlaşmaların boyutunu göstermektedir. Tablodaki verilerden de anlaşılacağı üzere, anlaşmaların büyük bir bölümünde tarım hâkim amaç konumundadır. Tarımsal amaçlarla yapılan anlaşmalar içerisinde ise hem amaçtan bahsedilme sayısı hem de toplam alan bakımından önemli bir faktör olmaya devam eden sebep gıda ürünleri üretimidir. Onu ise biyoyakıtlar izlemektedir.

Tablo 2: Arazi Edinimlerinin Amacı ve Boyutu, 2016

\begin{tabular}{|c|c|c|}
\hline Amaç & Amaçtan Bahsedilme Sayısı & $\begin{array}{l}\text { Toplam Anlaşma Boyutu } \\
\text { (Milyon Hektar) }\end{array}$ \\
\hline Tarım & 1403 & 24.1 \\
\hline -Biyoyakıtlar & 221 & 5.1 \\
\hline -Gıda Ürünleri & 553 & 9.2 \\
\hline -Hayvancıllk & 130 & 2.0 \\
\hline -Gıda Dışı Tarım Ürünleri & 236 & 2.3 \\
\hline -Tarım (Belirtilmemiş) & 263 & 5.6 \\
\hline Ormancilık & 187 & 12.0 \\
\hline Turizm & 25 & 1.7 \\
\hline Sanayi & 33 & 0.4 \\
\hline Koruma & 20 & 1.4 \\
\hline Yenilenebilir Enerji & 57 & 0.9 \\
\hline Diğer Amaçlar & 28 & 1.0 \\
\hline Bilgi Yoktur & 30 & 1.0 \\
\hline Toplam & 1783 & \\
\hline
\end{tabular}

(Nolte vd., 2016: 10)

Arazi edinim amaçlarının toplam anlaşmalar içerisindeki oranlarına bakılacak olursa, burada da tarımın ağırlı̆̆ından söz edilebilir. Tablodan hareketle, toprak gaspı anlaşmalarının daha çok tarımsal üretim faaliyetleri $(\% 78,6)$ amacıyla yapıldığ $(\% 10,4)$, yenilenebilir enerji $(\% 3,1)$, sanayi $(\% 1,8)$, hakkında herhangi bir bilgi olmayanlar $(\% 1,6)$, diğer amaçlar $(\% 1,5)$, turizm $(\% 1,4)$ ve koruma $(\% 1,1)$ takip etmektedir. Bununla birlikte, pek çok anlaşma birden fazla amaca yönelik olarak da yapılabilmektedir.

Anlaşmalar hangi amaçlarla yapılırsa yapılsın bazı riskler taşımakta ve hatta uygulamaya geçirilenlerin çoğunun olumsuz sonuçları olmaktadır. Bu sonuçlar çiftçilerden ekonomiye, sosyal adaletten insan haklarına, gıda güvenliğinden biyolojik çeşitlilik kaybına kadar geniş bir alanı kapsamaktadır. Bu konuyla ilgili birkaç örnek vermek konunun daha somut olarak anlaşılmasını sağlayacaktır. Burada özellikle belirtmek gerekir ki, toprak gaspının gerçekleştirildiği ülke sayısı oldukça fazla olmakla birlikte hakkında saha araştırması yapılan ve toprak satışları ile ilgili verilerine erişilebilen ülke sayısı bir hayli azdır. Dolayısıyla çalışma kapsamında seçilen ülkeler hem hakkında saha araştırması yapılan hem de toprak gaspının çeşitli düzeylerdeki etkisinin net olarak görülebildiği ülkelerdir. Bu kapsamda ilk olarak Etiyopya'nın kırsal bölgelerinden biri olan Oromiya Bölgesi'nde yabancı bir yatırımcı (Karuturi Agro Products Plc) tarafından başlatılan Bechera Tarımsal Kalkınma Projesine ve bu projenin etkilerine değinebiliriz. Şirket yetkilileri mısır, pirinç ve muz gibi ürünler yetiştirmek amacıyla Bako Ovası'nda 10.700 hektarlık bir alanı Etiyopya Hükümeti ile yapılan anlaşmalar sonucunda kiralamıştır. Projenin zarar verdiği alanlar çok çeşitlidir. Otlak alanlarının kaybı projenin en ciddi olumsuz etkisi olarak belirtilmektedir. Otlatma alanlarının kaybedilmesi durumunda, çiftçilerin hayvanlarını beslemekte zorlandıkları ve buna bağlı olarak da hayvan 
fiyatlarının \%20 ile \%35 oranında düştügü iddia edilmektedir. Söz konusu tarım projesinin endüstriyel tarım uygulamalarına dayalı olması halinde ise, su kaynaklarında bozulma, ekosistem kırılganlığında artma, proje alanı ve yakınındaki nehir sistemlerinde değişme ve biyolojik çeşitlilikte kayip beklenmektedir (Fisseha, 2011: 20, 30).

Toprak satışına ilişkin anlaşmaların olumsuz sonuçlar doğurduğu ülkelerden bir diğeri Mali'dir. Alman Teknik İş Birliği Şirketi'nin (GTZ) yayınladığı bir çalışmaya göre, Mali'de bugüne kadar 130.105 hektarlık alan doğrudan yabancı yatırımcı tarafindan teminat altına alınmıştır. Bu alanın 100.000 hektarlık kısmı Mali ve Libya arasında imzalanan bir yatırım anlaşmasının ardından Malibya Tarım şirketine verilmiştir. Şu anda 75.000 'den fazla insanın yaşadığı proje alanında başta pirinç olmak üzere diğer tarım ürünlerinin üretilmesi amaçlanmaktadır. Söz konusu çalışmada projenin hayata geçirilmesi ile ortaya çıkan ilk etkiler ve gelecekte yaşanması muhtemel etkilerden bahsedilmektedir. Bu kapsamda zaten görünür olan olumsuz etkilerden bazıları; insanların evlerinin boşaltılması ve bu evlere el konulması, kanal ve yol inşası nedeniyle evlerin, köylerin ve bahçelerin yıkılması, pek çok köyün sular altında kalması, bölgedeki tüm ormanların Malibya şirketi tarafından alınmasından dolayı yerel halkın gıda, ilaç, yakacak odun, yapı malzemesi ve hayvan yemi gibi ürünlere erişimini kaybetmesi, yaylacılık yollarının tıkanması, yerel taş ocakları ve hatta mezarlıkların bile yok edilmesidir. Bunların yanında beklenen etkiler de sıralanmaktadır. Sulanan alanlarda sulama suyu eksikliği, tarım arazilerinin kaybedilmesi, yerel nüfusun yerinden edilmesinin devam etmesi, geçim kaynaklarının bozulması, çölleşme ve tuzlanma riski ve mevcut geleneksel yaşam tarzının değişmesi gibi sorunlar bunlar arasındadır (Diallo ve Mushinzimana, 2009: 18, 20).

Büyük ölçekli arazi yatırımlarının hedefinde olan ve bu yatırımlardan olumsuz şekilde etkilenen ülkelerden bir başkası, Güney Amerika'da yer alan Kolombiya'dır. Nariño'nun (Kolombiya) güneybatı bölgesinde, yasal olarak yerli ve etnik gruplara ait topraklarda çok uluslu şirketler tarafindan yakıt elde etmek amacıyla palmiye yağı yetiştirilmektedir. Söz konusu girişimin sosyal, ekolojik, ekonomik ve politik alanlarda etkileri olmuştur. 35.000 hektarlık alan üzerinde yapılan palmiye yağı yetiştiriciliğinin yarattığı sorunlardan bazıları; palmiye ağaçlarına yer açmak ve alana erişim yolları inşa etmek nedeniyle ormansızlaşma, mikroiklim değişikliği, palmiye tarlalarının yakınlarındaki nehir ve kollarında bulunan balık sayısında gözle görülür azalma, yerel nehirlerdeki kirlenme ve kötü su yönetiminden kaynaklı olarak çeşitli hastalıklarda çoğalma, pek çok topluluğun gıda egemenliğini kaybetme riski ile karşı karşıya kalması, avcılık, balıkçılık ve geçimlik tarım gibi geleneksel faaliyetlerin kaybedilmesi, fumigasyon (tütsüleme) işleminden dolayı kronik ishal, solunum yolu hastalıkları, düşük vakaları ve bazı durumlarda ölüm ve fumigasyona tabi tutulan geleneksel ürünlerin kirlenmesidir. Bir de bunlara 2009 y1lından itibaren tomurcukların çürümesi sorunu eklenince küçük ölçekli çiftçiler için süreç daha da zor bir hal almıştır. Çürüme yaygınlaştıkça işten atılan insan sayısı artmış, hastalık yayıldıkça satacağı meyve miktarı düşen çiftçiler zarara uğramıştır. Soruna çözüm olarak sunulan hibrit tohumlar ise, çiftçilerin şirketlere olan bağımlılıklarını arttırmıştır (Maughan, 2011: 3, 22, 23).

Toprak gaspının dünya çapında yaygın bir gerçeklik haline gelmesi ve zarar verdiği alanların genişliğini göstermesi bakımından verilebilecek dördüncü örnek, AB ülkeleridir. İtalya'nın Narbolia kasabasında Enervitabio Limited Şirketi tarafindan kurulan güneş serası projesi ve etkilerinden bu kapsamda söz edilebilir. 64 hektarlık bir alana kurulan proje; 107.000 kurulu panel ve her biri 200 $\mathrm{m}^{2}$ olan 1.614 seradan oluşmakta ve 27 megawatt enerji üretim hedefiyle çalışmaktadır. Tesisin kurulmasıyla ortaya çıkan olumsuz etkilere gelinecek olursa, öncelikli olarak tesise verilen arazi nedeniyle kasabanın kullandığı mevcut alan azalmış ve buna bağlı olarak yerel tarım sistemi etkilenmiştir. Yerel toplulukların gıda üretme ve toprağa güvenli erişim hakları baltalandığı için gıda egemenliği üzerinde ciddi kısıtlamalar getirilmiştir. Çeşitli düzeylerde çevresel zarar ortaya çıkmışırı. Topraklar tarımsal kullanımdan uzaklaştıkça finansal spekülasyonların konusu haline gelmiştir. Üstelik söz konusu yatırım yerel tarım sektörüne çok az fayda sağlamıştır. İlgili iş firsatları veya diğer sosyal ve ekonomik avantajlar açısından yatırımın faydaları sınırlı düzeyde kalmıştır. Tüm bu sorunlardan dolayı projeye karşı çıkılmış ancak karşıt gösterilerde bulunanlar yetişkin ve çocuk ayrımı gözetilmeksizin tutuklanmıştır (Onorati ve Pierfederici, 2013: 71, 82, 88).

Yukarıda ayrıntılarına yer verilen Etiyopya (10.700 hektar), Mali (100.000), Kolombiya (35.000 hektar) ve İtalya (64 hektar) örneklerinden de anlaşılacağı üzere, toprak gaspının coğrafi 
kapsamı Afrika ülkeleri ile sınırlı değildir ve Güney Amerika, Avrupa gibi diğer kıtaları da içermektedir. Dünyanın hangi bölgesinde olursa olsun ve ne kadarlık bir alanı kapsarsa kapsasın yapılan toprak gaspı anlaşmaları çeşitli sorunları da beraberinde getirmektedir. Bunlar ise, edinilen toprakların tarım dışı amaçlarla kullanılmasından dolayı yerel toplulukların gıda üretme ve çiftçilik yapma haklarının baltalanması, çiftçilerin sahip olduğu ya da kullandığı arazi büyüklüğünün daralması, gıda üretiminin büyük oranda azalması, geçim kaynaklarının kaybedilmesi (Emenyonu vd., 2017: 154), toprak mülkiyeti konusunda belirsizliklerin ortaya çıkması, insanların bir yerden başka bir yere göç etmesi nedeniyle göç edilen yerlerdeki topluluklar üzerinde baskı oluşturulması (Colchester vd., 2006: 76), yerel ekosistemlerin çarpıcı bir şekilde değişmesi (Balehegn, 2015: 12), kitlesel yerinden edilme ve sosyal çatışmalardır (Neef, 2016: 6).

\section{KORUMA AMAÇLI TOPRAK EDINIMI (YEȘIL GASP) VE ÖRNEKLERİ}

Toprak gaspı tartışmalarının yürütüldügü çeşitli platformlarda kiralanan ya da satın alınan alanlar kadar bu alanların hangi amaçlarla kullanılacağ konudur. Daha önceki sayfalarda da belirtildiği gibi, toprak gaspında arazi kullanım amaçları taraflar arasındaki anlaşmalara bağlı olarak değişiklik göstermektedir. Bazı yatıımcılar aldıkları topraklarda gıda üretmeyi tercih ederken bazıları bu toprakları madencilik yapmak amacıyla kullanabilmektedir. Bunların dışında koruma amaçlı olarak toprak kiralayan ya da satın alanlar da vardır. Literatürde bu tarz toprak edinimlerine yeşil gasp denmektedir.

Kavram ilk olarak The Guardian gazetesi çevre editörü John Vidal tarafindan gündeme getirilmiş ve Vidal kavramı, yatırımcıların çevre koruma adına ülkeleri ve toplulukları kontrol altına alma girişimleri olarak tanımlamıştır (Vidal, 2008). Başka bir ifadeyle yeşil gasp, toprakların ve kaynakların çevresel amaçlar için tahsis edilmesi anlamına gelmektedir. Burada tahsis etmekten kasit, daha önce kamu ya da özel mülkiyete konu olan (hatta sahiplik konusu bile olmayan) kaynakların mülkiyetinin, kullanım haklarının ve kontrolünün yoksullardan güçlülerin eline geçmesidir (Fairhead vd., 2012: 238). Yani, yeşil gasp yalnızca belirli bir seçkin grup tarafından büyük ölçekli toprak alımlarını kapsamamakta bunun yanında korumanın ve hizmet edeceği amaçların yeniden tanımlanmasını da içermektedir. Korumanın yeniden tanımlanması ise, kapitalist pazar ve ilişkilerin yabancı yatırımcılar aracılığıyla yoksul alanlara kadar genişletilmesi amacına hizmet etmektedir (Büscher ve Dressler, 2012: 369). Dolayısıyla bazı yorumcular koruma hedeflerinin toprak gaspının bir parçası olduğunu iddia etmektedir (Blomley vd., 2013: 3). Dünya genelindeki koruma amaçlı toprak edinimi örneklerinin büyük bir çoğunluğu bu iddianın haklılığını doğrulamaktadır. Çünkü teoride koruma amacıyla alınan toprakların pratikte korumayı zayıflatan birer unsura dönüştükleri görülmektedir. Tablo 3'te bahsi geçen örneklerden bazılarına yer verilmekte ve çalışmanın bundan sonraki kısmı adı geçen örneklere referansla açıklanmaktadır. Bu örnekler, çevresel tahribatın sistem değişikliğine gerek olmadan, modernleşmeden vazgeçilmeden ve çevreye duyarlı birtakım yatırımlar ile çözülebileceğini iddia eden ekolojik modernleşme teorisinin temel savlarının çürütülmesi bakımından da dikkat çekicidir. (Huber, 2000: 16, 20, 23). 
Tablo 3: Dünya Genelindeki Bazı Yeşil Gasp Örnekleri

\begin{tabular}{|c|c|c|c|}
\hline Araştırmacı(lar) & Ülke & Alan & Etkileri \\
\hline $\begin{array}{l}\text { Nienke Busscher, } \\
\text { vd., } \\
(2018)\end{array}$ & Arjantin & $\begin{array}{l}88.000 \text { ha } \\
150.000 \text { ha }\end{array}$ & $\begin{array}{l}\text { Yerinden edilme, geçim kaynağ } \\
\text { kayıpları, iş faaliyetlerinde değişiklik, } \\
\text { toz kirliliği, su mevcudiyetinin } \\
\text { azalması }\end{array}$ \\
\hline $\begin{array}{l}\text { Dianne E. Rocheleau } \\
\text { (2016) }\end{array}$ & Meksika & 600 ha & $\begin{array}{l}\text { Yerinden edilme, tehdit, yaralama ve } \\
\text { öldürülme, yerel toplulukların toprak, } \\
\text { ürün ve hayvanlarını kaybetmeleri, } \\
\text { mekânın karakteri ve peyzajının } \\
\text { değişmesi }\end{array}$ \\
\hline $\begin{array}{l}\text { Diana Ojeda } \\
\quad(2011)\end{array}$ & Kolombiya & 15.000 ha & $\begin{array}{l}\text { Kaynaklar ve toprak üzerindeki } \\
\text { baskının artması, çalışanlar ve park } \\
\text { sakinlerinin yerlerinden edilmesi, } \\
\text { karar alma mekanizmalarında yer } \\
\text { almak istediklerinde tehdit edilmesi, } \\
\text { insanların hayatlarını kontrolünü } \\
\text { kaybetmesi }\end{array}$ \\
\hline $\begin{array}{l}\text { Elizabeth Lunstrum } \\
\qquad(2016)\end{array}$ & Mozambik & $35.000 \mathrm{~km}^{2}$ & $\begin{array}{l}\text { Alanda yaşayan toplulukların } \\
\text { yerlerinden edilmesi, geçim } \\
\text { kaynaklarının kaybedilmesi, göç } \\
\text { nedeniyle bazı yerleşim yerleri } \\
\text { üzerindeki baskının artması, sınırlı } \\
\text { düzeydeki su kaynaklarının } \\
\text { tükenmesi, ormanların yerini şeker } \\
\text { kamışna dayalı mono kültürün } \\
\text { alması, gida güvenliğinin tehlikeye } \\
\text { girmesi }\end{array}$ \\
\hline $\begin{array}{l}\text { Eria Serwajja } \\
\quad(2015)\end{array}$ & Uganda & $900 \mathrm{~km}^{2}$ & $\begin{array}{lcr}\text { Yerli toplulukların } & \text { yerlerinden } \\
\text { edilmesi, } & \text { köylülerin geçim } \\
\text { kaynaklarının } & \text { yok edilmesi, } \\
\text { tarlalarındaki } & \text { mahsullerine el } \\
\text { konulması, çocukların eğitim } \\
\text { haklarının ellerinden alınması, ortak } \\
\text { su kaynaklarının kontrolünün } \\
\text { kaybedilmesi }\end{array}$ \\
\hline
\end{tabular}

İlk örnek olarak, Arjantin'in kuzeydoğusundaki Corrientes eyaletinde bulunan ve bir koruma alanı olan Los Esteros del Iberá içinde ve çevresindeki toprak satışlarından bahsedilebilir. 2014 ve 2015 yıllarında Corrientes'de yapılan bir çalışmada, bahsi geçen sulak alanda iki farklı şekilde büyük ölçekli yatırım yapıldığg belirtilmektedir. Bunlardan birisi, endüstriyel ağaç yetiştirmek amacıyla yatırım yapan Harvard Yönetim Şirketi diğeri ise, ABD'li iş adamı Douglas Tompkins tarafından koruma amaçlı olarak yapılan yatırımdır. Toplam 42 birey ve 4 aile ile yapılan görüşmelere dayanan çalışmada her iki yatırım şeklinin de yeșil gasp olarak değerlendirilebileceği vurgulanmakta ve bu yatırımların çeşitli düzeylerdeki etkileri tartışılmaktadır (Busscher vd., 2018: 574). 
Harvard şirketine tahsis edilen 88.000 hektarlık alan sonucunda arazi kullanım koşullarında belirsizliklerin ortaya çıktığı, kayıt dışı arazi varlıkları konusunda endişelerin arttığı, insanların yerlerinden edildiği, yerlerini terk edenlerin yoksulluğa mahkûm olduğu ve geçim kaynaklarını kaybettiği, iş faaliyetlerindeki değişiklikten (sığır yetiştiriciliğinden ormancılığa geçiş) dolayı yerel halkın rahatsızlık duyduğu, alandaki trafiğin artmasından dolayı toz kirliliği, kaza riski, sağlık ve güvenlik sorunlarının yaşandığı, ekilen alanların yüksek oranda su tüketimi gerektirmesi nedeniyle su mevcudiyetinin azaldığı ve buna bağlı olarak insanların suya erişiminin kısıtlandığı ifade edilmektedir (Busscher vd., 2018: 577). Diğer yatırımcı Tompkins'in satın aldığ1 150.000 hektarlık alanda da benzer sorunlar ile karşılaşılmıştır. Tompkins'in yatırımları ve bölgedeki varlığı yerel halkı rahatsız etmiş ve halk bu yatırımların egemenliklerini etkileyeceği konusunda endişelenmişlerdir. Ayrıca Tompkins bir okulu yasa dışı bir şekilde kapattırmak ve toplumu savunmasız hale getirerek kuşatmakla suçlanmıştır (Busscher vd., 2018: 578).

Buradan hareketle, adı geçen yatırımların koruma şemsiyesi altında doğayı metalaştıran sermaye birikim stratejileri olduğunu söylemek yanlış olmayacaktır. Başka bir ifadeyle, her iki yatırım şekli de yeşil gaspın etkilerinin toprak üzerindeki kontrolün ele geçirilmesi ile sınırlı tutulamayacă̆ını göstermektedir. Yeşil gasp olarak nitelendirilen bu örnekler tüm yönetim sistemindeki değişikliğe işaret etmektedir. Burada esas sorun yeşil gaspçıların alana yatırım yapması değildir bu gaspçıların önündeki engellerin yerel halkın aleyhine olacak şekilde ortadan kaldırılmasıdır. Bu karşıt gelişmeler ise, toplumun ilgi ve ihtiyaçlarının görmezden gelinmesi, toprak mülkiyetindeki yabancı etkinliğinin artması, eşitsizliklerin çoğalması, yerel halkın sürece dâhil edilmemesi, bir firsat olması gereken yatırımların geçim kaynaklarını tehdit eden bir unsura dönüşmesi ve çevresel bozulmanın yaratılmasıdır.

Toprağın ve ilgili diğer kaynakların teminini haklı çıkarmak amacıyla çevresel nedenlerin kullanılmasına yönelik ikinci örnek olarak, Meksika'nın Chiapas kentindeki Ekoturizm Projesi verilebilir. Söz konusu topraklara yatırım yapılarak kalkınmanın sağlanması, yoksulluğun azaltılması ve bu yolla korumanın temin edilmesi planlanmaktadır. Başlangıçta bu amaçlar herhangi bir sorun yaratmak bir yana tercih edilebilir seçenekler olarak düşünülebilir. Ancak projenin etkileri beklenildiği gibi olumlu sonuç vermemiştir. Planın hayata geçirilmesi ile birlikte insan ve toprak arasındaki bağlantı koşulları yeniden tanımlanmış ve koruma bahanesiyle 40'tan fazla topluluk tahliye edilmiştir (Rocheleau, 2016: 705). Yerel topluluklar yalnızca topraklarını, ürünleri ve hayvanlarını kaybetmemiş projeye karşı direndikleri için yaralanmış ve hatta bir kısmı öldürülmüştür. Önerilen turizm projesi alanında yer alan Agua Azul ve yakınındaki toplulukların yaşamış olduğu deneyimler bu olumsuzlukların en net olanlarıdır.

Projeye bağlı olarak mekânın karakteri ve mekânı çevreleyen peyzaj değişmiş, nehir, havuz, orman, tarla ve evlere erişim yolları farklılaşmışıtır. Proje kapsamında yapılacak olan otoyol nedeniyle kasabalar, evler, tarlalar, işletmeler, kiliseler, kamu binalan ve meydanlar etkilenmiştir (Rocheleau, 2016: 707). Yapılan planlarda özellikle bazı toplulukların alandan çıkartılması istenmiştir. Çünkü bu alanlar üzerinde lüks bir yağmur ormanı tesisi ve arkeolojik gezi alanı yapılması tasarlanmıştır. Yani satın alınan arazi yerli halkın çıkarılması yoluyla karbon dengeleme projeleri için ormanlara, ticari monokültür ekimine veya diğer ticari kullanımlara ayrılmaktadır (Rocheleau, 2016: 707, 711). Tüm bu gelişmeler sonucunda ise, topraklar ve insanlar çeşitli çıkarc1 ve sömürücü güçlerin hizmetine açılmaktadır. Bu nedenle Chiapas'taki yeşil gaspçıların mülksüzleştirme yoluyla birikimlerini arttırma arayışında olduklarını söylemek yanlış olmayacaktır.

Yeşil gasp yatırımlarının görünenden çok daha büyük ve karmaşık bir ilişkiler ağından oluştuğunu gösteren üçüncü örnek, Kolombiya'nın kuzey kıyısındaki Tayrona Milli Parkı'dır. 15.000 hektarlık bir alan üzerine kurulu olan parktaki turizm hizmetleri 2005 yılında 10 yıllığına Aviatur (seyahat şirketi) ve Alnuva (seyahat acentası) şirketlerine devredilmiştir. Mülkiyeti konusunda tartışmaların (bazılarına göre alanın \%90'ı özel mülkiyet altında bazılarına göre ise, kamu mülkiyetinde) devam ettiği ulusal parkın el değiştirmesi ile kaynaklar ve toprak üzerindeki baskı artmış, çalışanlar ve park sakinleri yerlerinden edilmiş, yerel topluluklar alanla ilgili kararlarda dışarıda bırakılmış, umursanmamış, talep ettikleri ya da karşı çıktıkları zaman ise tehdit edilmişlerdir (Ojeda, 2011: 16). Yaşanan sorunlar bunlarla sınırlı kalmamış şirketlerle yapılan anlaşmalar şirket kurallarına göre hareket edilmesini gerektirdiği için insanlar zamanlarının, kazançlarının ve işlerinin 
kontrolünü kaybetmişlerdir.

Örneğin, alanı çok iyi bilen ve daha önceleri tur rehberi olan insanların büyük bir bölümü şirket yatırımları sonucunda Aviatur için valiz taşıyan görevliler haline gelmişlerdir. Benzer şekilde, parkta meyve suyu ve su satarak hayatta kalmaya çalışan orta yaşlı iki kadın şirket tarafindan istenmemiş, önce kadınların büfeleri daha az görünür bir yere taşınmış daha sonrasında ise şirket onları parktan kovmuştur. Ayrıca yerel halkın koruma gerekçesiyle (deniz kaplumbağalarının yuvalama alanı olmasından dolayı) samandan bir çatı bile yapmasına izin verilmeyen alanda şirketlere yenilenmiş kamp alanları, banyolar, restoranlar, lüks kulübeler, jakuziler, yüzen yataklar, spa ve bar alanları yapma hakkı tanınmıştır. Esasen tüm bu değişiklikler aracılığıyla yapılmak istenen şey, parkın kontrolünden ziyade insanların yaşamlarının kontrol edilmesi (Ojeda, 2011: 17-18) ve parkın halkın kullanımından ziyade elitlerin kullanımına sunulmasıdır. Bu yüzden Tayrona Milli Parkı'ndaki toprak satışlarıyla ve bu satıştan elde edilecek gelirle deniz kaplumbağalarının, mercan resiflerinin, uluyan maymunların, sahillerin, çalışanların ve ormanların korunacağı iddia edilmekle birlikte uygulamada alanın seçkin bir yapıya kavuşturulması yönünde atılan adımlarla bu amaçların göz ardı edildiği görülmektedir.

Yeşil gasp yatırımlarının toprak gaspı mekanizmalarının tamamlayıcısı ve bir birikim stratejisi olduğunu gösteren dördüncü örnek, Mozambik'teki Limpopo Milli Park1 ve bu parkla ilgili gelişmelerdir. 2002 y1lında bir proje kapsamında Güney Afrika'daki Kruger, Mozambik'teki Limpopo ve Zimbabwe'deki Gonarezhou milli parkları Büyük Limpopo Sınır Ötesi Parkı (GLTP) adı altında birleştirilmiş ve parkın $35.000 \mathrm{~km}^{2}$ lik bir alanı kapsadığı ifade edilmiştir. Dünyanın en büyük koruma alanını oluşturduğu iddia edilen bu girişimle, geniş ve kesintisiz yaban hayatı manzarası yaratılmak istenmiştir. Bunun için söz konusu üç küçük koruma alanının sınırlarında bazı değişiklikler gerçekleștirilmiştir. Ayrıca sınırlar turistlere de açılarak, alanın içerisinde Giriyondo Turist Erişim Merkezi (GLTP) kurulmuştur. Böylece turistlere GLTP'nin Mozambik ve Güney Afrika bölümleri arasında kolayca seyahat etme şansı tanınmış ve merkez aracılığıyla Mozambik hükümetinin sermaye üretmesinde yardımcı olunmuștur. Ancak bu girișimlerin Mozambik Limpopo Milli Parkı içerisinde yaşayan topluluklar üzerinde olumsuz etkileri olmuştur (Lunstrum, 2016: 145).

En derin etkilerden birisi, parkın iç kısmında yaşayan yaklaşık 7.000 kișinin tahliye edilmesidir. Söz konusu toplulukların tahliye edilme gerekçelerinden ilki, toplulukların alanda ekolojik zarara sebep olmalarıdır. Bir diğer tahliye gerekçesi, sınırların açılmasıyla yaban hayatının serbestçe alanda hareket edebilmesi ve buna bağlı olarak insan güvenliğinin tehdit altında olmasıdır. Üçüncü gerekçe ise, Limpopo Milli Parkında köylülerin yaşadığı alandaki su zenginliğinin alana gelecek olan turistlerin ihtiyaçlarının karşılanması noktasında oldukça önemli bir rol oynayacağıdır (Lunstrum, 2016: 145-146). Toprak satışının etkileri yerli toplulukların yerlerinden edilmesi ile sınırlı kalmamaktadır. Yerlerinden edilen insanların nereye yerleşecekleri ya da yerleştirilecekleri konusu da bir başka sorundur. Bu da belirli alanlara doğru göçe neden olmakta ve bazı yerleşim yerlerinin üzerindeki baskıyı arttırmaktadır. Bir anlamda sınırın yaban hayatı, turistler ve gergedan avcıları için açılması beraberinde parkın bir parçası haline gelen toplulukların ve geçim kaynaklarının ortadan kalkmasını da getirmektedir (Lunstrum, 2016: 146).

Bununla da yetinilmeyerek tahliye edilen alanlar devlet tarafindan özel yatırımcılara şeker kamışı/etanol üretimi amacıyla tahsis edilmektedir. Başka bir ifadeyle, toplulukların Kruger'in gergedanlarından uzağa ve turistlerin görüşünün ötesine yerleştirilmek istenmesinin esas sebebi, zengin mineral kaynakları ve büyük ekilebilir arazileri olan Mozambik'in özel yatırımcılara açılmasıdır. Yani, topluluklar imtiyazlara yakın olmakla birlikte imtiyaz sahibi olamamaktadır. Çünkü özel yatırımcılar insanların emeğine değil topraklarına ihtiyaç duymaktadır (Lunstrum, 2016: 146-147). Dolayısıyla tüm bu girişimler sınırlı düzeydeki su kaynaklarının tükenmesine, ormanların yerini şeker kamışı mono kültürünün almasına, sınırların açılmasıyla fillerin toplulukların çiftliklerine zarar vermesine ve gıda güvenliğinin tehlikeye girmesine neden olmuştur (Lunstrum, 2016: 149).

Yeşil gaspın toprak gaspını hızlandıran sürecin önemli bir parçası olduğunu gösteren beşinci örnek, Uganda'nın Amuru Bölgesi'ndeki yaban hayatı rezervlerinin Güney Afrika vatandaşlarına ait Lake Albert Safaris Limited Şirketi'ne tahsisidir. Şirket söz konusu alanı spor amaçlı avcılık, turizm ve vahşi yaşamı korumak amacıyla satın aldığını belirterek bu yolla yaban hayatı popülasyonunun 
iyileştirileceğini, bitki örtüsünün korunacağını ve yerel toplulukların gelir elde etmesinin sağlanacağını iddia etmektedir (Serwajja, 2015: 14). Ancak diğer ülke örneklerinde olduğu gibi Uganda örneğinde de, teori ve pratik arasında büyük bir boşluk olduğu görülmektedir. Uganda' daki devlet ve devlet kurumlarının korumaya öncelik veren ve özel girişimlerin alana girişini kolaylaştıran politika değişiklikleri bazı olumsuz etkilere neden olmuştur. En temel sorunlardan birisi, Amuru Bölgesi’ndeki Apaa köyünde yapılacak olan av sahası nedeniyle yerli toplulukların yerlerinden edilmesidir. Av sahasının koruyucu ve bekçileri tarafından alanda 800 kişinin barınmasını sağlayan kulübeler yıkılmış, köylülerin geçim kaynakları yok edilmiş ve tarlalarındaki mahsullerine el konulmuştur. Evleri ve mahsulleri imha edilen insanlar ise topraklarını terk etmek zorunda kalmıştır (Serwajja, 2015: 7).

Apaa köyünde av sahasının sınırlarının belirlenmesi sürecinde de bazı sorunlar ile karşılaşılmıştır. Köylüler üzerinde yaşadıkları toprakların meşru sahibi olduklarını belirterek, hükümetin topraklarını yaban hayatı rezervi ilan edebilmesi için kendilerine danışması gerektiğinin altını çizmektedir. Bunun gerekçesi olarak da Uganda Cumhuriyeti Anayasasını göstermektedir (Sewajja, 2015: 7-8). Köylülerin muhalefetine rağmen söz konusu alan yaban hayatı rezervi içerisine dâhil edilmiş, bununla da yetinilmeyerek köylüler meşru sahibi oldukları topraklardan uzaklaştırılmıştır. Hâlbuki yaban hayatının korunmasını sağlamak amacıyla teşvikler yaratmak bu alanların korunması için yeterli bir faktör değildir buna ek olarak alanın çevresindeki yerel toplulukların da korunan alanların yönetimine katılması gerekmektedir (Lindsey, 2008: 41-47).

Bölgedeki toprak tahsisi nedeniyle ortaya çıkan bir başka sorun, tahliyeler esnasında Apaa köyü topluluğu tarafindan inşa edilen ilkokulun bir polis birimine dönüştürülerek öğrencilerin derslere devam etmesinin engellenmesidir. Yani, okulun öğrencilerin kullanımından çıkarılarak polis birimi haline getirilmesi yoluyla çocukların eğitim hakları ellerinden alınmıș olmaktadır. Eğitime erişimin engellenmesi ise, çocukların hem okul ortamında hem de çevreleriyle inşa ettikleri sosyal ağların bozulmasına neden olmaktadır (Sewajja, 2015: 23-24). Köylünün karşılaştığı sorunlar bunlarla sınırlı kalmamış, Apaa köylüleri hayatta kalmalarında oldukça önemli bir etken olan ortak su kaynaklarının kontrolünü de kaybetmişlerdir. Bunun sebebi ise, köy merkezindeki su kaynăğ olan sondaj kuyularının yıkılmasıdır. Su kaynaklarının yıkılmasına bağlı olarak hastalıklar ortaya çıkmış, su kaynakları tahrip edilen köylüler alternatif su kaynakları için 7 km'den fazla yol yürümek zorunda kalmıştır. Burada özellikle belirtmek gerekir ki, yeni su kaynakları hayvanlar ile birlikte ortak olarak kullanılmaktadır (Sewajja, 2015: 24).

Tüm bu sorunlar Apaa köylülerinin tahliyesi ile yalnızca geçim kaynaklarını kaybetmediklerini bunun yanında kimliklerini ve aidiyetleri tanımlayan topraklara erişimlerini de yitirdiklerini göstermektedir. Bir de buna tahliyelere direnen gençlerin tutuklanması ve bazı insanların öldürülmesi eklenince sorunun boyutu daha da derinleşmiştir (Sewajja, 2015: 25-26). Buradan hareketle, bir tür iyilik olarak kabul edilen yabancı yatırımların Uganda özelinde de beklenileni karşılamadığı tam tersine mülksüzleştirme yoluyla sermaye birikim süreçlerini kolaylaştırdığı söylenebilir.

\section{SONUÇ VE DEĞERLENDİRME}

Son dönemlerde basında sık sık gündeme gelen ve bazı araştırmalara konu olan arazi satın alımı ve/veya kiralanması-toprak gaspı olgusunun ne anlama geldiği, kavramın içeriğinin nasıl doldurulduğu, satın alınan topraklar korumaya tahsis ediliyorsa buna toprak gasp1 denilip denilemeyeceği ve çevresel amaçlarla toprağa el koymanın mümkün olup olmayacağı gibi soruların yanıtına ulaşmak amacıyla ortaya konan bu çalışmada, toprak gaspı girişimlerinin büyük bir çoğunluğunda başlangıçta vaat edilen hususların uygulamada yerine getirilmediği ve bu girişimlerin geliştirici değil mevcut durumu daha da kötüleştirici tarafları olduğu anlaşılmaktadır. Bu kapsamda çalışmada varılan sonuçlar şu şekildedir:

Öncelikli olarak toprak gaspı kavramının tanımı ve kapsamına ilişkin bir netliğin olmadığını söylemek ve bu konu ile ilgili tartışmaların devam ettiğini belirtmek gerekir. Ecoruralis Derneği, Uluslararası Arazi Koalisyonu ve Birleşmiş Milletler Gıda ve Tarım Örgütü çeşitli kriterler üzerinden ne tür bir işlemin toprak gaspı olarak kabul edilebileceğine ilişkin görüş bildirmekle birlikte bu 
tanımlamalar bazı açılardan sorunludur. Eğer toprak gaspı yalnızca büyük ölçekli toprak edinimi olarak değerlendirilirse bu küçük ölçekli toprak kiralama ve/veya satışlarının gasp kapsamı dışında tutulmasına neden olacaktır. Bu durumda çalışma kapsamında üzerinde durulan İtalya örneği 64 hektarlık faaliyet alanı (güneş serası projesi) nedeniyle toprak gaspı içerisine dâhil edilemeyecektir. Hâlbuki söz konusu projenin kasabada yaşayan halk üzerinde ciddi düzeylere varan olumsuz etkileri olmuştur.

Bir başka tanımlama kriteri olan yabancı yatırımcılar üzerinden konuya yaklaşılacak olursa, bu sefer de toprak gaspı ile ilgili aktörlerin kapsamı daraltılmış olacak ve yerli yatırımcıların eline geçen topraklarda herhangi bir sorun yaşanmadığına yönelik bir anlayış ortaya çıkacaktır. Bu sebeple, esas üzerinde durulması gereken konu, olgunun boyutu ve olgu ile ilgili aktörlerden ziyade olgunun etkileri olmalıdır. Çünkü gaspın boyutu ve kimler tarafindan gerçekleştirildiğinden bağımsız olarak, bütün girişimler yerli halkın yerlerinden edilmesine, geçim kaynaklarını kaybetmesine, su kaynaklarının tahrip edilmesine, yerel gida sistemlerinin bozulmasına ve gida egemenliklerini kaybetme riski ile karşı karşıya kalmalarına neden olmaktadır.

Koruma amaçlı toprak edinimleri (yeşil gasp) toprak gaspının bir parçası ve tamamlayıcısı olarak değerlendirilebilir mi? sorusunun cevabı ise, söz konusu girişimlerin de toprak gaspı sürecini hızlandırdığı ve desteklediği yönündedir. Çünkü yeşil gasp girişimlerinde yatırımcılar çevre koruma adına toprakları kiraladıklarını ve/veya satın aldıklarını belirtmekle birlikte, girişimlerin sonucunda ortaya çıkan tablo toprak gaspı ile hemen hemen aynıdır. Ancak yeşil gasp girişimlerinde arazi edinim amacı çevresel koruma adı altında yapıldı ğı için bu yatırımlar daha az dikkat çekebilmektedir. Hâlbuki dünya genelindeki çeşitli yeşil gasp örnekleri (Arjantin, Meksika, Kolombiya, Mozambik ve Uganda) doğanın alınıp satılabilen birer metaya nasıl dönüştürüldüğünü gösteren işaretlerle doludur. $\mathrm{Bu}$ tarz toprak edinimlerinde doğal kaynakların korunabilmesi için yine aynı doğal kaynakların satılması gerektiği vurgulanmaktadır. $\mathrm{Bu}$ ise uygulamaya mülksüzleştirme yoluyla sermaye birikimi şeklinde yansımaktadır. Yani, yeşil gasp girişimleri tahrip edilen doğanın tamir edilebilmesi için yeni pazarlar yaratılmasının bir sorun oluşturmayacağı anlayışına dayanmaktadır. Sözü edilen şekilde tıpkı toprak gaspında olduğu gibi kapitalist endüstrinin genişletilerek devam ettirilmesi için yeni bir alan yaratılmış olmaktadır.

Doğayı koruma ve ekolojik sürdürülebilirliği sağlama amacıyla hareket ettiğini iddia eden ve bir taraftan da doğayı bir kârlılık aracı olarak gören girişimlerin bahsettikleri korumayı sağlayabilmeleri mümkün değildir. Uygulamadaki yeşil gasp örnekleri metalaştırmanın korumanın etkili bir aracı olamayacağını göstermektedir. Metalaştırma nedeniyle ortaya çıkan sorunlar yalnızca ekonomiyi, sosyal adaleti ve insan haklarını etkilememekte aynı zamanda doğaya da ciddi zararlar vermektedir. Doğanın zarar görmesi durumunda ise, özellikle az gelişmiş ve gelişmekte olan ülkelerde yaşayan kırsal topluluklar hem geçim kaynaklarını hem de gıdaya erişim haklarını kaybetmektedir. Topraklarını kaybeden ve çoğunlukla direnme gücü de olmayan bu topluluklar ellerinde kalan tek seçeneği takip ederek kente göç etmektedir. Bu da zaten artan kentleşme hızını daha da arttırmaktadır. Hâlbuki kırsal alanlardan kentsel alanlara doğru göçe neden olan böyle bir mekanizmayı kullanmak ve teşvik etmek yerine küçük üreticilerin desteklenmesi ve en temel üretim araçlarından birisi olan topraklarının korunması gerekmektedir. Doğayı ve ona bağlı küçük üreticileri çeşitli aktörler (özellikle çokuluslu şirketler) karşısında koruyacak olan ise, devletlerdir. Dolayısıyla, doğayı korumak amacıyla ortaya atılan yeşil gasp girişimlerinin korumak bir yana çevresel tahribatı daha da şiddetlendirdiğini ifade etmek yanlış olmayacaktır. Doğayı korumanın tek yolunun ise, yıkımından sorumlu sisteme son verilmesi ile mümkün olacağı belirtilmelidir.

\section{KAYNAKÇA}

Baker-Smith, K. ve Miklos Attila, S. B. (2016). What is Land Grabbing? A Critical Review of Existing Definitions, Romania: Ecoruralis.

Balehegn, M. (2015). Unintended Consequences: The Ecological Repercussions of Land Grabbing in SubSaharan Africa. Environment: Science and Policy for Sustainable Development, 57(2), 4-21.

Blomley, T., Flintan, F., Nelson, F. ve Roe, D. (2013). Conservation and Land Grabbing: Part of the Problem or Part of the Solution? London: International Institute for Environment and Development. 
Borras Jr, Saturnino M., Kay, C., Gómez, S. ve Wilkinson, J. (2012). Land Grabbing and Global Capitalist Accumulation: Key Features in Latin America. Canadian Journal of Development Studies, 33(4), 402-416.

Broughton, A. (2013). Land Grabbing: A New Colonialism. Green Social Thought 61: A Magazine of Synthesis and Regeneration, 25-29.

Busscher, N., Parra, C. ve Vanclay, F. (2018). Land Grabbing within a Protected Area: The Experience of Local Communities with Conservation and Forestry Activities in Los Esteros del Iberá, Argentina. Land Use Policy, 78, 572-582.

Büscher, B. ve Dressler, W. (2012). Commodity Conservation: The Restructuring of Community Conservation in South Africa and the Philippines. Geoforum, 43(3), 367-376.

Cochrane, L. (2016). Land Grabbing, David M. Kaplan ve Paul B. Thompson (Ed.), Encyclopedia of Food and Agricultural Ethics (s.1-5), Netherlands: Springer.

Colchester, M., Jiwan, N., Sirait, M., Firdaus, A. Y., Surambo, A. ve Pane, H. (2006). Promised Land: Palm Oil and Land Acquisition in Indonesia- Implications for Local Communities and Indigenous Peoples, Indonesia: Forest People Programme, Perkumpulan Sawit Watch, HuMa ve World Agroforestry Centre.

Deininger, K., Byerlee, D., Lindsay, J., Norton, A. Selod, H. ve Stickler, M. (2011). Rising Global Interest in Farmland: Can It Yield Sustainable and Equitable Benefits?, Washington, D.C :The World Bank.

Diallo, A. ve Mushinzimana, G. (2009). Foreign Direct Investment (FDI) in Land in Mali, Eschborn: Deutsche Gesellschaft für Technische Zusammenarbeit (GTZ).

Emenyonu, C., Nwosu, A., Eririogu, H. I. ve Osuji, M. (2017). Analysis of Land Grabbing and Implications for Sustainable Livelihood: A Case Study of Local Government Areas in Nigeria. Journal of Economics and Sustainable Development, 8(8), 149- 157.

Fairhead, J., Melissa, L. ve Scoones, L. (2012). Green Grabbing: A New Appropriation of Nature?. Journal of Peasant Studies, 39(2), 237-261.

Feldman, S. (2012). Land Expropriation and Displacement in Bangladesh. Journal of Peasant Studies, 39(34), 971-993.

Fisseha, M. (2011). A Case Study of the Bechera Agricultural Development Project, Ethiopia: CIRAD ve International Land Coalition.

Franco, J. C., Borras, S., Fradejas, .A. ve Buxton, N. (2013). The Global Land Grab: A Primer, Revize Edilmiş Bask1, Netherlands: Transnational Institute.

Gómez, S. (2014). The Land Market in Latin America and the Caribbean: Concentration and Foreignization, Santiago: Food and Agriculture Organization of the United Nations.

Graham, A., Aubry, S., Künnemann, R., and Suárez, S. M. (2010). CSO Monitoring 2009-2010 Advancing African Agriculture (AAA): The Impact of Europe's Policies and Practices on African Agriculture and Food Security.

https://afrique-europe-interact.net/files/englisch 10 fianetal land grab study europeaninvolvement.pdf adresinden 12 Aralık 2020 tarihinde edinilmiştir.

Hall, R., Edelman, M., Borras Jr, Saturnino M., Scoones, I., White, B. Ve Wolford., W. (2015). Resistance, Acquiescence or Incorporation? An Introduction to Land Grabbing and Political Reactions 'From Below. Journal of Peasant Studies, 42(3-4), 467-488.

Heinrich Böll Stiftung. (2015). Toprak Atlası: Toprak, Araziler ve Tarlalar Hakkındaki Olgular ve Rakamsal Veriler 2015, Almanya: Heinrich Böll Stiftung.

Huber, J. (2000). Towards Industrial Ecology: Sustainable Development as a Concept of Ecological Modernization. Journal of Environmental Policy and Planning, 2(4), 269-285.

International Land Coalition. (2011). Tirana Declaration. https://www.landcoalition.org/en/aboutilc/governance/assemblydeclarations/2011-tirana/ adresinden 3 Nisan 2020 tarihinde edinilmiştir.

Kelly, A. B. (2011). Conservation Practice as Primitive Accumulation. Journal of Peasant Studies, 38(4), 683701.

Land Matrix. (2019a). https://landmatrix.org/charts/intention/ adresinden 22 Kasım 2019 tarihinde edinilmiştir. 
Land Matrix. (2019b). https://andmatrix.org/charts/web-of-transnational-deals/ adresinden 21 Kasım 2019 tarihinde edinilmiştir.

Lindsey, P. A (2008). Trophy Hunting in Sub Saharan Africa: Economic Scale and Conservation Significance, Rolf D. Baldus, Gerhard R. Damm ve Kai-Uwe Wollscheid (Ed.), Best Practices in Sustainable Hunting: A Guide to Best Practices from Around the World (s. 41-47), Hungary: International Council for Game and Wildlife Conservation (CIC).

Lunstrum, E. (2016). Green Grabs, Land Grabs and the Spatiality of Displacement: Eviction from Mozambique's Limpopo National Park. Royal Geographical Society, 48(2), 142-152.

Maughan, M. J. (2011). Land Grab and Oil Palm in Colombia. International Conference on Global Land Grabbing (s. 1-32). United Kingdom: University of Sussex.

Murmis, M. ve Murmis, M. R. (2012). Land Concentration and Foreign Land Ownership in Argentina in the Context of Global Land Grabbing. Canadian Journal of Development Studies, 33(4), 490-508.

Neef, A. (2016). Land Rights Matter! Anchors to Reduce Land Grabbing, Dispossession and Displacement: A Comparative Study of Land Rights Systems in Southeast Asia and the Potential of National and International Legal Frameworks and Guidelines, Berlin: Brot für die Welt.

Nolte, K., Chamberlain, W. ve Giger, M. (2016). International Land Deals for Agriculture, Fresh Insights from the Land Matrix: Analytical Report II, CDE, CIRAD, GIDA, University of Pretoria, Bern Open Publishing.

Ojeda, D. (2011). Whose Paradise? Conservation, Tourism and Land Grabbing in Tayrona Natural Park, Colombia. International Conference on Global Land Grabbing (s. 1-32). United Kingdom: University of Sussex.

Onorati, A. ve Pierfederici, C. (2013). Land Concentration and Green Grab in Italy: The Case of Furtovoltaico in Sardinia, Jennifer Franco and Saturnino M. Borras Jr. (Ed.), Land Concentration, Land Grabbing and People's Struggles in Europe (s. 70-90), Transnational Institute for European Coordination Via Campesina and Hands off the Land Network.

Oxfam. (2011). Land and Power: The Growing Scandal Surrounding the New Wave of Investments in Land, Oxfam Briefing Paper, Nairobi: Oxfam.

Özkaya, O. (2018). Türkiye'de Toprağını Sat, Sudan'da Toprak Kirala. https://www.aydinlik.com.tr/turkiyede-topragini-sat-sudan-da-toprak-kirala-ozgurluk-meydani-mayis-2018 adresinden 13 Nisan 2020 tarihinde edinilmiştir.

Rocheleau, D. E. (2016). Networked, Rooted and Territorial: Green Grabbing and Resistance in Chiapas. Journal of Pesant Studies, 42 (3-4), 695-723.

Serwajja, E. (2015). The Twists and Turns of the Green Land Grab in Apaa Village of Amuru District, Northern Uganda, by Lake Albert Safaris Ltd. Annual World Bank Conference on Land and Poverty (s. 1-31). Washington DC.

Su Hakk1 Kampanyası. (2016). Son Y1lların Küresel Trendi: Toprak Gaspı. https://www.suhakki.org/2016/08/son-yillarin-kuresel-trendi-toprak-gaspi/ adresinden 22 Kasım 2019 tarihinde edinilmiştir.

Vidal, J. (2008). The Great Green Land Grab. https://www.theguardian.com/environment/2008/feb/13/conservation, adresinden 21 Ocak 2020 tarihinde edinilmiştir.

Von Braun, J. ve Meinzen-Dick, R. (2009). "Land Grabbing" by Foreign Investors in Developing Countries: Risks and Opportunities, Research Report of the International Food Policy Research Institute, Washington, DC: International Food Policy Research Institute.

Zoomers, A. (2010). Globalisation and the Foreignisation of Space: Seven Processes Driving the Current Global Land Grab. The Journal of Peasant Studies, 37(2), 429-447. 


\section{EXTENDED SUMMARY}

\section{Purpose}

It is not a new development for domestic and/or foreign investors to buy agricultural land in their country borders and/or developing countries worldwide. However, especially after the problem of increasing food prices occurred in 2008 and 2009, the process has progressed faster than previous years. As in international academic arena, this issue is a research topic in Turkey as well. However, these studies are mostly carried out in terms of the causes of the land grabbing, the extent of the agreement processes and the struggles against the land grabbing attempts. Yet, there are several other issues that are as important as as the size of the agricultural land purchased, the buyer or seller. One of these issues is the criteria that is used to define a purchase as land grabbing or not, while another is about the purpose of use and the party/parties benefiting from it more. Land grabbing for protection purposes seems to be a versatile and controversial area to be discussed thoroughly.

Therefore, in this study, an inquiry is taking place to find out whether the phenomenon of renting and/or purchasing agricultural land for protection purposes can be evaluated within the scope of land grabbing. In order to reach the answer to this question, the discussion is not only made on a theoretical basis but the topic is made formalized by analyzing the five cases of green grabbing taken place worldwide.

\section{Methodology}

In this study, a theoretical discussion about land grabbing is carried out primarily because it is aimed to analyze land acqusitions (green grabbing) with reference to land grabbing. Generally, the publications and studies of Ecoruralis Association, International Land Coalition and United Nations Food and Agriculture Organization are used. The reason for this is that the concept of land grabbing has been defined in the literatüre based on the criteria in those publications. However, it is stated in this study that the mentioned criteria may have misleading dimensions in order to understand the land grabbing phenomenon correctly, and the examples of green grabbing were analyzed based on social impact criterion. The examples of green grabbing discussed in the study were limited to countries such as Argentina, Mexico, Colombia, Mozambique and Uganda. The reas1-on fort his preference is both about revealing the extent of geographical scope of the grabbing and the fact that the land acquisitions in these countries contain dramatic results in terms of impact categories. Therefore, not only theoretical determinations were made in the study, but also the study was deepened via field research and the outcomes. Thus, an inquiry to answer to the questions about whether there is a gap between theoretical investigations and practices related to land grabbing and how the theory reflects on practice was made.

\section{Findings}

There is no mention of a common criterion for the concept and context of land grabbing. Ecoruralis Association, International Land Coalition and United Nations Food and Agriculture Organization have made various attempts to define the concept. Ecoruralis Association has defined the concept on the criteria of size, subject, control, compliance with the law and usage method. International Land Coalition evaluated the issue within the framework of considering several matters like consent, human rights, gender, transparency of agreement processes and participation. United Nations Food and Agriculture Organization has tried to reveal the fundamental features of the concept through scale, foreign state participation and food safety. However, the examples in practice offers us to question the accuracy of these criteria. For example, if the issue is considered only within the scope of large-scale land grabbing, this will cause small-scale acquisitions to be ignored. For this reason, lookinf at the effects of land grabbing within the criteria of social impact will make the analysis more reliable.

\section{Conclusion and Discussion}

The starting question of this study is whether the attempts of land leasing or purchasing for protection allocation by domestic or foreign companies can be called land grabbing and it is answered by these initiatives should also be evaluated as such. Thre rationale for this is social impacts of green grabbing attempts in Argentina, Mexico, Colombia, Mozambique and Uganda. The displacement of indigenious communities, the loss of livelihoods, the abolition of educational rights of their children, 
their exclusion from decision-making processes, the increasing pressure over resources, the depletion of limited water supplies, the increase in monocultural implementations, losing control over common water resources, deteriorating the character and landscape of the space and endangering food safety are some of those social impacts 